\section{Healthcare systems, the State, and innovation in the pharmaceutical industry}

\author{
Sistemas de atenção à saúde, Estado e inovação \\ na indústria farmacêutica
}

\author{
Sistemas de salud, Estado e innovación en la \\ industria farmacéutica
}

\begin{abstract}
This article discusses the relations between healthcare systems and the pharmaceutical industry, focusing on state support for pharmaceutical innovation. The study highlights the experiences of the United States, United Kingdom, and Germany, developed countries and paradigms of modern health systems (liberal, universal, and corporatist), in addition to Japan, a case of successful catching up. The study also emphasizes the experiences of China, India, and Brazil, large developing countries that have tried different catching up strategies, with diverse histories and profiles in their healthcare systems and pharmaceutical industries. Finally, with a focus on state forms of support for health research, the article addresses the mechanisms for linkage between health systems and the pharmaceutical industry, evaluating the possibilities of Brazil strengthening a virtuous interaction, favoring the expansion and consolidation of the Brazilian health system - universal but segmented - and the affirmation of the innovative national pharmaceutical industry.
\end{abstract}

Drug Industry; Health Systems; Public Policies; Sustainable Development; Innovation

\author{
1 Universidade Federal de Juiz \\ de Fora, Juiz de Fora, Brasil. \\ Correspondence \\ I. J. G. Delgado \\ Universidade Federal de \\ Juiz de Fora. \\ Rua Padre Anchieta 92, \\ Juiz de Fora, $M G$ \\ 36016-440, Brasil. \\ ignaciogdelgado.ufjf@gmail.com
}




\section{Introduction}

Do the different configurations of healthcare systems in their respective national territories affect the modalities of state support for innovation in the pharmaceutical industry?

This is the basic question of the current article, which provides a brief exploratory overview of this relationship in the United States, United Kingdom, Germany, Japan, China, India, and Brazil. The first three countries adopted liberal, universal, and corporate models in their national healthcare systems. As developed countries with advanced national innovation systems $1,2,3$, they also have outstanding pharmaceutical industries, among the main leaders in pharmaceutical innovation. Japan, with a corporate-type healthcare systems, joined the group of developed countries using a successful economic and technological catching up strategy, although the country's pharmaceutical industry (while important) does not show the same innovative performance as other industrial sectors in the country, lagging behind the industry indicators of the United States, United Kingdom, and Germany. China, India, and Brazil have healthcare systems with diverse profiles and degrees of consolidation. Cited as innovative developing countries in health 4 , they have adopted different strategies for technological catching up and learning 5 for the economy as a whole and the pharmaceutical industry, with a different weight for foreign investment, licensing for use of technologies, and acquisition of complete technological packages (passive learning systems), as opposed to prevalence of investment by domestic companies, reverse engineering, and stimulus for endogenous innovation (active learning systems).

An innovative pharmaceutical industry has positive impacts on the health conditions of populations that access to its products 6,7 . Based on science 8 , it draws on research propelled by public and/or academic institutions 9,10, by definition public goods, inclusive and indivisible. Meanwhile, the impetus for innovation is associated with its appropriation by companies 11 (referring to the intricate debate on patent law, intensified since publication of the Trade-Related Aspects of Intellectual Property Rights - TRIPS Agreement in 1995) 12 and with the reduction of different sectors' uncertainties as to the possibility of future gains 13,14. In innovative countries, the state thus acts to create spaces for cooperation between companies and institutions in the science and technology system, participates in financing research, and sustains demand through government purchases 15,16. This article contends that the government's role in conducting such policies in health, and the relevance of such policies for the innovation strategy in the different cases, is associated with the nature of the national healthcare systems. In short, health policies have played an increasingly important role in industrial and innovation policy targeting the sectors that supply inputs to the health area 17, and this has played out in different ways according to the healthcare systems in the respective national territories.

The health innovation system extends beyond healthcare provision itself to encompass regulatory agencies, science and technology agencies, and different production areas, with companies operating according to specific logics (medicines and medical equipment) in dynamic interaction with healthcare professionals (especially physicians), hospitals, and the national healthcare system 15,18 . In addition, the world is witnessing the emergence and expected strengthening of a global health innovation system 19 , with the purpose of filling gaps in science, the market, and public health in poor countries through the affirmation of industrial development networks and partnerships that extend beyond national borders. However, this emerging scenario does not rule out the role of the national state, which continues in developed and innovative developing countries as a decisive agent in the formulation and conduction of health and innovation policies. In addition, the national space is still central to the operation of the health industrial complex, involving relations of "buying and selling good services services" and "knowledge and technologies" in "very particular political and institutional contexts" which establish "the health market as a political and institutional construction" 20 (p. 5).

The health market, a political and institutional construction as indicated above, refers largely to the environment demarcated by the weight and scope of the national healthcare systems. In the next section we address how these affect the modalities of government participation in supporting the pharmaceutical industry. In the Final Remarks we suggest a reflection on the possibilities, in the Brazilian context, of interaction between the Brazilian Unified National Health System (SUS) and the national pharmaceutical industry which would both favor the affirmation of the public dimension of the SUS and reinforce the disposition for innovation by the pharmaceutical industry. 
Healthcare systems and the pharmaceutical industry

Typologies of healthcare systems vary greatly 21 . Here, we distinguish between them based on users' eligibility/entitlement and the supply/ provision of services $15,22,23$. Thus, based on the patterns first defined in central countries, the paradigms are liberal systems, in which access is mainly through the market to predominantly private services, with means tests used for entitlement to enroll in public programs (United States); universal systems, funded by general taxes, where entitlement is basically associated with citizens' rights and services provided by the state (United Kingdom, Scandinavia) or by private providers (Canada); corporate systems, funded by employers' and workers' contributions, with the social security logic prevailing and entitlement defined by predominantly occupational criteria and diversified (private and public) services provision. Tables 1 and 2 indicate some characteristics of the healthcare systems in the countries covered in this article, in addition to socioeconomic data that jointly determine the overall health conditions of their populations, partially reflected by some indicators.

Unlike physicians, companies, workers, and the state, the pharmaceutical industry rarely considered in studies on the implementation of modern national healthcare systems $24,25,26$. The nature of healthcare systems has not been an obstacle to their development, which is significant in countries with liberal, universal, and corporate systems. Under different configurations, the health area of government has sought to regulate the production of medicines by setting standards for research, production, quality, marketing, and access. However, there are diverse national market structures for both pharmaceutical products themselves and the arrangements to support production and innovation in the sector.

In the United States, health has been a central theme on the public agenda since World War II, simultaneously with the affirmation of large pharmaceutical corporations, recruited by government for the production of medicines needed in the war effort 7,9,27. In subsequent decades,

Table 1

Key data on selected national healthcare systems.

\begin{tabular}{|c|c|c|c|c|c|c|c|c|}
\hline Country & $\begin{array}{l}\text { Inauguration } \\
\text { of the current } \\
\text { system }\end{array}$ & Entitlement & Hospital network & $\begin{array}{l}\text { Physicians } \\
\text { (principal } \\
\text { professional } \\
\text { situation) }\end{array}$ & $\begin{array}{l}\text { Health } \\
\text { expenditure/ } \\
\text { GDP * } \\
\text { (\%) }\end{array}$ & $\begin{array}{c}\text { Public } \\
\text { expenditure/ } \\
\text { total health } \\
\text { expenditure * } \\
\text { (\%) }\end{array}$ & $\begin{array}{l}\text { Total per } \\
\text { capita } \\
\text { expenditure } \\
\text { on health * } \\
\text { (US\$) }\end{array}$ & $\begin{array}{c}\text { Per capita } \\
\text { government } \\
\text { expenditure } \\
\text { on health * } \\
\text { (US\$) }\end{array}$ \\
\hline Germany & 1883 & Insurance & $\begin{array}{l}\text { Some } 2 / 3 \text { public } \\
\text { (mostly municipal) }\end{array}$ & $\begin{array}{c}\text { Liberal, public } \\
\text { service }\end{array}$ & 11.3 & 76.5 & 4,474 & 3,420 \\
\hline Brazil & 1988 & $\begin{array}{l}\text { Universal/ } \\
\text { Segmented }\end{array}$ & $\begin{array}{l}\text { Public and private } \\
\text { (majority) }\end{array}$ & Liberal & 8.9 & 45.7 & 1,035 & 474 \\
\hline China & 1998 & Insurance & $\begin{array}{l}\text { Public (majority) } \\
\text { and private }\end{array}$ & $\begin{array}{c}\text { Public service } \\
\text { (dispense } \\
\text { medicines) }\end{array}$ & 5.1 & 55.9 & 423 & 236 \\
\hline USA & 1965 & Means test & $\begin{array}{c}\text { Predominantly } \\
\text { private }\end{array}$ & Liberal & 17.7 & 47.8 & 8,467 & 4,047 \\
\hline India & 1983 & Residual & Public and private & Liberal & 3.9 & 30.5 & 146 & 44 \\
\hline Japan & 1961 & Insurance & Some $50 \%$ public & $\begin{array}{l}\text { Public service/ } \\
\text { Liberal (dispense } \\
\text { medicines) }\end{array}$ & 10.0 & 82.1 & 3,415 & 2,804 \\
\hline $\begin{array}{l}\text { United } \\
\text { Kingdom }\end{array}$ & 1948 & Universal & Public & Public service & 9.4 & 82.8 & 3,364 & 2,787 \\
\hline
\end{tabular}

GDP: Gross Domestic Product.

* Data for 2012, obtained in World Health Organization (World health statistics part III: global health indicators. http://apps.who.int/iris/bitstream/

10665/112738/1/9789240692671_eng.pdf?ua=1, accessed on 10/Dec/2014). 
Table 2

Health indicators and living conditions in selected countries.

\begin{tabular}{|c|c|c|c|c|c|c|}
\hline Country & $\begin{array}{l}\text { Hospital beds per } 10,000 \\
\text { inhabitants }\end{array}$ & $\begin{array}{l}\text { Physicians per } 10,000 \\
\text { inhabitants }\end{array}$ & $\begin{array}{l}\text { Neonatal mortality rate } \\
\text { per } 1,000 \text { live births }\end{array}$ & $\begin{array}{l}\text { Life expectancy } \\
\text { (years) }\end{array}$ & $\begin{array}{l}\text { Per capita income } \\
\text { (US\$ thousand) * }\end{array}$ & HDI ** \\
\hline Germany & 82 & 34.1 & 2 & 81 & 47.64 & 0.911 \\
\hline Brazil & 23 & 18.9 & 9 & 74 & 11.53 & 0.744 \\
\hline China & 38 & 14.6 & 9 & 75 & 7.38 & 0.891 \\
\hline USA & 29 & 24.5 & 4 & 79 & 55.2 & 0.914 \\
\hline India & 7 & 7.0 & 31 & 66 & 1.57 & 0.586 \\
\hline Japan & 137 & 23.0 & 1 & 84 & 42.00 & 0.890 \\
\hline United & 29 & 27.9 & 3 & 81 & 42.69 & 0.892 \\
\hline Kingdom & & & & & & \\
\hline
\end{tabular}

HDI: Human Development Index.

* Data for 2014, obtained in World Bank (World development indicators data base. http://data.worldbank.org/data-catalog/world-development-indicators/ wdi-2014, accessed on 18/Dec/2014).

** Data from United Nations Department Programme 92.

government health research funding through the National Institutes of Health (NIH), part of the Department of Health and Human Services (HHS), spearheaded government spending on research in the United States and was crucial to most of the innovations developed by companies 10,28. More recently, programs have been stepped up that involve HHS agencies, universities, and companies, like the Critical Path Initiative of the U.S. Food and Drug Administration (FDA) and the NIH Roadmap for Medical Research, especially the Accelerating Medicines Partnership and the Clinical and Translational Science Award (CTSA) Program 29,30,31,32.

The United States does not regulate the price of medicines, and market dynamics are basically determined by private demand. Medicaid (for the poor) and Medicare (for the elderly) covered less than $30 \%$ of the U.S. population in 201233 . Public financing through HHS agencies and public-private partnerships are the principal instruments for stimulating innovation. Government purchases are only important for innovation when associated with the fight against pandemics and/or for military purposes, as in the case of contracts signed by the Biomedical Advanced Research and Development Authority (BARDA), under the Office of the Assistant Secretary for Preparedness and Response of the HHS, or the Defense Advanced Research Programs Agency (DARPA) of the Department of Defense 34,35,36.

In the United Kingdom, government purchases play a decisive role in stimulus for innovation. Only $12 \%$ of the UK population is covered by private insurance 37 . The domestic market for production by sectors of the health industrial complex is thus a quasi-monopsony of the National Health System (NHS). As in the United States, World War II propelled the pharmaceutical industry 38 , but it was the Pharmaceutical Price Regulation Scheme (PPRS) (established in 1957) that according to the Association of the British Pharmaceutical Industry (ABPI) provided a "receptive commercial environment" for innovation, guaranteeing feasible profit margins for the industry, although simultaneously aiming at reasonable costs for the NHS 39 . The NHS also plays a leading role in financing research through the National Innovation Centre (NIC) 40 and the National Institute for Health Research (NIHR) 41, created in 2006 as part of the Best Research for Best Health strategy, which aimed to affirm the "NHS as an internationally renowned research centre" 42 , strengthening research-friendly culture and clinical research and highlighting the hospital as the cornerstone of the British health innovation system 43 .

British pharmaceutical companies have lobbied for flexibilization of medical prescriptions in the NHS in order to expand the domestic absorption of the industry's production, which far outstrips the internal demand. There are also persistent efforts to step up NHS partnership in research, seen as a comparative advantage in international competition. Since the creation of the Pharmaceutical Industry Task Force in 1999, such efforts appear in negotiations with the British government, particularly in the Ministerial Industry Strategy Group (MISG), headed by the Department of Health. These resulted in the Long Term 
Leadership Strategy, launched in 2005, spinning off in initiatives like the MISG Clinical Research Workgroup, Early Access Working Group, Vision for the UK-Based Bioscience Industry, tax incentives for the industry, Innovation Pass (for early incorporation of new medicines in the NHS), and the Office for Life Sciences. Companies have also lobbied for use of Connecting for Health, which collects information on therapeutic procedures used in NHS patients, seeking an additional advantage for British industry in international competition 16 .

In Germany, Statutory Health Insurance (SHI), the most important component of the healthcare system, currently includes 131 funds for employees and their dependents, covering $85 \%$ of the population. The rest is covered by Private Health Insurance (PHI) and special arrangements. Long-term care is guaranteed by Long Term Care Insurance (LTCI). Forty-eight percent of Germany's hospital beds are in public hospitals, mostly municipal, and the rest in non-profit (34\%) and for-profit establishments (18\%). The states control the university hospitals 44,45 . With such fragmentation, as far as medicines are concerned the health system does not play a significant role in policymaking and implementation to support innovation. Such policies are concentrated in the Federal Ministry of Education and Research (Bundesministerium für Bildung und Forschung - BMBF). Purchase of medicines by the funds is decentralized and does not follow an overall strategy to support innovation. Since 2010 there have been limits on purchases above the reference prices (the lowest for equivalent formulations), allowing negotiations for drugs with proven effective therapeutic gain, setting higher prices for two years 46,47 .

German industry led innovation, production, and the world pharmaceutical market from the mid-19th century to World War II, when it was overtaken by the United States, and has remained since WWII as one of the world's five leading industries 7. Various major universities and research institutes participate in collaborative projects with the pharmaceutical industry 48,49 . In innovation policy for the industry, outstanding projects include those of the BMBF such as the Pharmaceuticals Initiative for Germany 50, launched in 2007, and the Health Research Framework Programme 51. Other programs are spinoffs of global initiatives such as the HighTech Strategy of the European Union, like the BioPharma Competition and the Leading Edge Cluster Competition 52 .

The German case suggests that corporate systems, due to their fragmentation, reduce the government health area's coordinating capacity for policymaking and implementation in innovation, and such policies are carried out with a relative disconnection between operation of the health system and industry. Among the developed countries analyzed here, the British health system, universal with public provision, is the least expensive (considering total and public per capita health costs), while showing a positive impact on the population's health conditions (Tables 1 and 2). Meanwhile, it plays an important role in stimulating innovation (despite the dilemmas associated with administration of a broad services network), connecting to industry through public purchases and direct support for research. Public provision of healthcare services makes hospitals important links between science and technology institutions and industry, through basic and applied research, clinical trials, and data collection on therapeutic efficacy of medicines and medical devices. Except for university hospitals, predominantly private hospitals are less likely to play such a role in liberal systems. In these, more than government purchases, public research funding acts as the principal link between industry and the health system, headed by agencies that are largely unburdened by management of the healthcare services network. At any rate, public-private partnerships or industrial development partnerships are relevant to research in this setting.

The recent Japanese experience corroborates the above. The Japanese health system is structured in two arrangements (by occupation and by region), the so-called Health Insurance and National Health Insurance, totaling more than 3,600 funds, with $55 \%$ of the hospital network in private hands, mostly for-profit 53,54. Their creation in 1961 reinforced the pharmaceutical industry's post-WWII growth pattern, induced by health policy and led by the Ministry of Health and Welfare (MHW), given the demand resulting from expansion of care, legislation for the approval of new drugs (flexible for domestic companies and rigid for foreign companies), marketing of medicines by physicians (especially prescriptions and sales), and price and reimbursement policy (remunerative for both industry and physicians) 55. The country's industrial policy complemented this arrangement through protection for the domestic market and permissive patent legislation. Thus, except for the production of antibiotics, with some inclination to research and development (R\&D), an imitative industry was consolidated, averse to exports and reverse engineering: a foreign body in Japan's overall industrial policy, led in other sectors by the Ministry of Industry, Trade, and Innovation (MITI). 
Changes in this scenario between 1967 and 1975 resulted from the following: pressure by the government's economic area to cut healthcare costs; changes in patent legislation and treatment of foreign capital in the pharmaceutical industry, linked to Japan's growing involvement in the community of developed capitalist nations; and the impact of the molecular biology revolution on the government's research agenda, through the MITI 55. In the 1990s, price controls and production of generics led Japanese companies to step up exports and diversify production for the domestic market, once again in collaboration with Japanese physicians, who preferred to prescribe more expensive patented medicines 56 . Contrary to other activities, the attraction of foreign capital and joint ventures were consolidated in the industry's policy aimed at technology transfer to compensate for the R\&D deficit inherited from previous policies.

The MHW maintained part of its leadership in policymaking for the industry, as evidenced by the Pharmaceutical Industry Vision (2002-2007), the New Vision for the Pharmaceutical Industry (2007-2011), and the Pharmaceutical Affairs Law (PAL) of 2005, with prospective and regulatory content 57,58. Still, the Ministry of Economy, Trade, and Industry (METI) (the new name for the MITI) has played an increasingly important role through the Biotechnology Strategy Guidelines (2002) 59 of the National Bioresource Project (NBRP) (2002-2010) 60 of the Industrial Cluster Plan Policy (2001-2011) 61. The formulation and implementation of policies oriented towards innovation thus tend to be increasingly dissociated from the government health area, which in Japan has been historically linked to an innovation-shy industry. Even so, Japan's pharmaceutical industry, unlike its other industries, has not been a leading player in innovative activity in the international scenario, although occupying second place in the world pharmaceuticals market since the 1960s and in global pharmaceutical production, basically targeting the domestic market. In $R \& D$ expenditures, among the main producing regions, Japan still lags far behind the United States and Europe 49,62.

Thus far we have addressed the relations between health systems and the pharmaceutical industry in developed countries with mature innovation systems. We will now focus on these relations in China, India, and Brazil.

The economic reforms launched by China in 1978 dissolved centralized financing of the health system (centered on production units, locations, and communes), expanding individual costing of medicines and services. From 1980 to the late 20th century, most Chinese citizens had no health insurance 63 . The pharmaceutical industry, regulated exclusively by the market, experienced great expansion and fragmentation with limited innovative effort induced by the sale of medicines by doctors and hospitais 64 . From 1998 to 2003, the Chinese government adopted a new approach, seeking (among other purposes) to expand social protection and the economy's endogenous innovative capacity, which had previously shown limited effectiveness in attracting multinationals through joint ventures, central to the policy options in the 1990s 65,66 . In health, from 1998 to 2007 the country established the Urban Employee Basic Medical Insurance (UEBMI), the New Cooperative Rural Medical Scheme (NCRMS), and the Urban Resident Basic Medical Insurance (URBMI). In 2009 China announced its Health Reform, aimed at full universalization by 2020 . By 2011 practically the entire population was enrolled in some healthcare coverage although with limited scope 63,67. As for the pharmaceutical industry, the new orientation resulted in regulatory measures and industrial and innovation policy. The regulatory measures targeted production, quality, marketing, prescription, and prices of medicines, manufacturing of generics, and reform of the country's patent legislation 68 .

In the midst of other industrial and innovation policy measures, the policy for endogenous innovation featured two major initiatives: the National Long-Term Program for Science and Technology (2006-2020) and Strategic Emerging Industries, in 2009 65,69. The first established three megaprojects in health, aimed at creating new varieties of genetically modified organisms, innovation, pharmaceutical development, and treatment of AIDS, hepatitis, and other serious diseases. The second highlights biotechnology as one of the strategic emerging industries and research consortia led by government ministries or inter-ministerial groups in policy operations involving universities, institutes, and companies, without excluding multinational corporations as long as they develop innovation registered in China and Chinese brand names 70 . Also relevant are the budget allocations, investments by stateowned banks, standards, fiscal and tariff measures, government purchases, and catalogues defining the beneficiary companies 71 .

The impact on the pharmaceutical industry appears important, since it is one of the three leading activities generating the most patent applications in China in the 21st century. From 2000 to 2009, the country moved from sixth place in pharmaceutical patent applications to second, now trailing only the United States 72 . Multinational corporations have participated in R\&D activities, especially clinical trials, attracted by the 
research infrastructure, trained personnel, and contract research organizations, but their role has decreased in terms of pharmaceutical patent applications in China: multinationals accounted for $30.10 \%$ of such applications in 2007 , but only $17.38 \%$ by 201072 .

From 1978 to 2003, the links between the Chinese healthcare system and the pharmaceutical industry were associated with the demand induced by over-prescribing in a protected domestic market and precarious regulation, stimulating fragmented and rudimentary production. This situation has still not changed appreciably. However, the presence of pillar and strategic companies in long-term projects involving different players has increased the weight of innovation in Chinese industry as a whole, including the pharmaceutical industry 65 . The health area does not predominantly lead pharmaceutical industrial policy, but it does play a relevant role, heading inter-ministerial groups that conduct strategic project linked to them, as in the case of the 2006 plan.

India has numerous government initiatives for health, but with limited effectiveness. The country has five public insurance schemes, targeting public employees, the elderly, and the poor (Central Government Health Scheme GHS, Employee State Insurance Scheme - ESIS; General Insurance Corporation - GIC; Life Insurance Company - LIC, and Community Health Insurance-CHI). The market also has other private and public health plans 73 . In the 21st century India has created the National Rural Health Mission, the National Urban Health Mission, and the Rashtriya Swasthya Bima Yojana (RSBY) program for hospital care for families below the poverty line 74. The 12th Five-Year Plan (2012-2017) further provided for the implementation of a Universal Health Coverage system by 2017 75. Still, the country's health indicators are extremely negative, and population coverage is negligible (Tables 1 and 2). According to estimates in 2005, only $3 \%$ to $5 \%$ of the population was covered by some health insurance 76. From 2009 to 2011, nearly $80 \%$ of health expenditures were out-ofpocket, two-thirds of which for medicines 77,78 . Thus, the links between the public health system and industry tend to be residual, only appearing occasionally in government purchases of medicines and vaccines.

In the 1970s, pharmaceutical production in India moved into the domain of domestic companies, expanding until 1995, propelled by domestic demand with precarious regulation and low prices 68,79. From that point on, as a low-income country, India took advantage of loopholes in TRIPS to increase the industry's for- eign sales. Since 2005 the country has adapted fully to TRIPS, reviewed its patent legislation, and sought to establish close-to-international standards. The industry was opened to foreign capital, which accelerated its entry into the country through mergers, acquisitions, and joint ventures, aimed at lower labor costs, the teaching and research system inherited from the country's post-Independence experience, and Indian contract research organizations, which detain an important share of this market. Production of biological medicines is significant, based on policies that have existed since the 1980s 68 .

India is now one of world's leading producers of medicines, especially generics and active ingredients 68 . However, the pharmaceutical industry is based on a duality that cuts across the country's entire economy 65,80. Targeting the segmented and scarcely dynamic domestic market, large companies coexist with small and medium-sized ones, concentrated on the production of generics and traditional medicines, but oriented preferentially to exports, the prime object of partnerships with institutes, universities, and public policies 68. In the Department of Science and Technology, these feature the Drugs and Pharmaceutical Research Program, linked to the Pharmaceutical Research and Development Support Fund, headed by Drug Development Promotion Board 81. The biologicals sector is spearheaded by the National Biotechnology Development Strategy, of 2007. Besides the Department of Science and Technology, linked to the Ministry of Science and Technology, the Department of Pharmaceuticals of the Ministry of Chemicals and Fertilizers head policies in the industry, harboring units of the National Institute of Pharmaceutical Education and Research (NIPER), the state-owned pharmaceutical companies, and the National Pharmaceuticals Pricing Authority (NPPA) 68.

In Brazil, the creation of the SUS in 1988 established a universal public system, dependent on the predominantly private healthcare services network. Meanwhile, government funding for health never reached levels consistent with other healthcare systems with universal entitlement, favoring the consolidation of private plans, whose action was approved in the 1988 Constitution as "supplementary healthcare". The result has been a segmented system, consecrated institutionally in 1998 with the creation of the Brazilian National Health Agency (ANS), alongside the National Health Council, previously the highest tier in the healthcare system's regulation 16,82,83,84. Still, the presence of the SUS not only had a positive impact on the Brazilian population's health conditions, it was also decisive for the national pharmaceutical industry's recent performance. 
Until the 1990s the Brazilian industry operated in a protected and internationalized domestic market and developed in an imitative pattern, averse to innovation and dependent on importing active ingredients 85 . Adherence to TRIPS in 1996 eliminated the possibility of imitation without costs threatening the very existence of domestic pharmaceutical companies -, placing enormous pressure on the SUS and aggravating the health sector's balance of payments problem. This scenario triggered policies that allowed the sector to react, expanding the domestic companies' presence on the domestic market and increasing investments in innovation, although without reversing the trade imbalance or dependence on importation of active ingredients $86,87,88$. Milestones included the generics legislation in 1999; the creation of PROFARMA as part of the Industrial, Technological, and Foreign Trade Policy (PITCE) in 2004; the More Health program in association with the Industrial Development Policy (PDP) in 2008; and the industrial development partnerships, intensified with the Greater Brazil (Brasil Maior) policy of 2011 16,17,70.These policies mobilized various instruments such as financing by banks and government agencies, tax breaks, and government purchases. Since 2010, government purchases can draw on a preference margin to favor domestic companies and stimulate innovation. From the institutional point of view, since launching of the Industrial Development Policy (PDP), industrial policy management for the health industrial complex was transferred to the Ministry of Health through the Executive Group of the Health Industrial Complex (GECIS), under the Secretariat for Science, Technology, and Strategic Inputs (SCTIE), which participates defining government purchases and industrial development partnerships, but with little influence on research funds, located in other areas of government.

The expansion of the pharmaceutical industry in China is not linked basically to operation of the health system, which is in the process of rapid consolidation. In addition, health authorities participate in programs targeting the pharmaceutical industry, and government purchases are becoming increasingly important for industrial policy. There is a strong orientation towards exportation of active ingredients, as in India, which is also an important exporter of generics. In China, the endogenous innovation policy aims to move the country from secondary to primary innovation, enhancing its importance in international value chains, strengthening Chinese companies and brands, and targeting various sectors of economic activity, thereby favoring the pharmaceutical industry. The policy has had considerable impact on innovation indicators as a whole (Table 3). In India, strengthening of the pharmaceutical industry has replicated the characteristics of the science and technology system and related sectors, insulated from the population and economy as a whole, drawing on links to a small portion of the population with the English-speaking academic and economic circles and low-cost (but skilled) labor. As a whole, India's industrial policy has highlighted the importance of improving the business environment with more active policies for a few sectors 65. Attraction of foreign capital is also important. The impacts on overall innovation indicators are modest, although there has been important growth in filing and approval of patents (mostly for incremental innovations) in the pharmaceutical and information technology industries, with a significant presence of non-residents 89 . As of 2010, no new chemical entity (NCE) developed by Indian companies had been approved for marketing in any country 90 . In Brazil, recent expansion of the pharmaceutical industry and the industry's awakening to innovation activities have still not guaranteed any future break with the industry's characteristic dependency, reflecting a passive learning system for innovation. Brazil's recent industrial policy has not significantly changed the country's overall innovation indicators (Table 3). Even so, there has been significant growth in R\&D investment in the pharmaceutical industry and in the health area as a whole 91 .

\section{Table 3}

Expenditures on innovation as percentage of Gross Domestic Product (GDP).

\begin{tabular}{cccc}
\hline Year & Brazil (\%) & China (\%) & India (\%) \\
\hline 2000 & 1.02 & 0.90 & 0.75 \\
2001 & 1.04 & 0.95 & 0.73 \\
2002 & 0.98 & 1.07 & 0.71 \\
2003 & 0.96 & 1.13 & 0.71 \\
2004 & 0.90 & 1.23 & 0.74 \\
2005 & 0.97 & 1.32 & 0.78 \\
2006 & 1.01 & 1.39 & 0.77 \\
2007 & 1.10 & 1.40 & 0.76 \\
2008 & 1.11 & 1.47 & - \\
2009 & 1.17 & 1.70 & - \\
2010 & 1.16 & 1.76 & - \\
2011 & - & 1.84 & - \\
\hline
\end{tabular}

Souce: United Nations (Regional and country profiles. http://stats.uis.unesco.org/unesco/TableViewer/document. aspx?Reportld=136\&IF_Language $=$ eng\&BR_Topic $=0$, accessed on Nov/2013). 


\section{Final remarks}

The consolidation and deepening of the mutually advantageous linkage between the Brazilian health system and the Brazilian innovation industry do not depend only on maintaining the policies underway in recent years. For such purposes, it is crucial to establish institutional arrangements that enhance the linkage between the government area in health, industry, and public research funding agencies to define and conduct the national health research agenda and especially the consolidation of Brazil's universal health system. In the United Kingdom and the Scandinavian countries, hospitals have been identified as key components in the operation of the national health innovation systems 18,43. In Brazil, the limited presence of public provision in the healthcare system limits properly exploiting the virtues favored by interaction with industry for innovative activity.

The overwhelming presence of private health plans, private hospitals, liberal medicine, and commercial laboratories and pharmacies on the Brazilian landscape also hinder the abovementioned virtuous operation, especially by strengthening players and dispositions contrary to the expansion of the public system. Still, we should not forget that this same landscape, with the variations existing since the 1980s, was unable to prevent the creation of the SUS. At the time, the Brazilian Health Reform movement could not even rely on decisive action by potentially important stakeholders such as organized workers. Although trade union confederations (e.g., Workers' Unitary Central - CUT) came out publicly with official statements supporting the SUS, they themselves were already enmeshed in private healthcare arrangements, company health plans, and even trade union health plans. The success of the Health Reform movement re- sulted from a political conjuncture in which embattled minorities achieved success against scattered adversaries, especially when the victory did not mean someone else's defeat, as in the case of preserving the private sector as "supplementary healthcare". Creation of the SUS has tremendous historical significance. In fact, beyond major improvement in health indicators, the SUS has created an environment that allows glimpsing a scenario of growing opportunities for virtuous interaction between the health system and innovative development.

While in the 1980s the Brazilian Health Reform movement achieved success through its specific action in a favorable political context, the scenario unveiled by industrial policies targeting the health industrial complex in recent years creates new opportunities, now with the possibility of building an unprecedented coalition in favor of health and development. For those that defend the universal health system and national industry, the expansion of public healthcare provision is something to be conquered for the benefit of all. It is true that we cannot rewrite our own history, and it makes no sense to imagine that the private business sector will disappear from health. That is not the point. It is important to reduce the dependency of the SUS on private hospitals and to increase public provision in order to additionally secure an important infrastructure for the development of collaboration with the industry for innovative activity. Without this, the recently created opportunities may be short-lived. While the United Kingdom is an unattainable mirage, India may always haunt us, without the consolidation of a strong domestic business sector in productive segments of the health industrial complex, having collaboration with the public system as a central element in their business strategies. This is certainly no easy task. But it is crucial to try.

\section{Acknowledgments}

I wish to thank the anonymous peer reviewers for their comments and suggestions, contributing greatly to the article. Thanks also to Fernando Marcus Nascimento Vianinni and Nittina Anna Araújo Bianchi Botaro, PhD students in History at the Federal University of Juiz de Fora (UFJF), in addition to Marina Brandão Mendes Regazzi, Taissa Cristina de Oliveira, and especially Raphael de Oliveira Lago and Samara Vitral Marinho, undergraduate scholarship students in History at UFJF.
I am especially grateful to Laís Silveira Costa for the opportunity to participate in the Health and Development Project: New Approaches in the Health Innovation Group (GIS) of the Oswaldo Cruz Foundation (Fiocruz), and to the Foundation for Scientific and Technological Development in Health (Fiotec) for providing the necessary support for me to conduct the research. I naturally assume full responsibility for the article's content. 


\section{References}

1. Nelson R. National innovation systems - a comparative analyses. Oxford: Oxford University Press; 1993.

2. Lundvall BA. National innovation systems - analytical concept and development tool. In: DRUID Tenth Anniversary Summer Conference 2005 on Dynamics of Industry and Innovation: Organizations, Networks and Systems. http://www.druid. $\mathrm{dk} /$ conferences/Summer2005/Papers/Lundvall.pdf (accessed on 09/May/2014).

3. Bernardes A, Albuquerque E. Cross-over, thresholds, and interactions between science and technology: lessons for less-developed countries. Res Policy 2002; 32:865-85.

4. Morel CM, Broun D, Dagni A, Elias C, Gupta RK, Haycock J, et al. Health innovation in developing countries to address diseases of the poor. Innovation Strategy Today 2005; 1:1-15.

5. Viotti EB. National learning systems: a new approach on technological change in late industrializing economies and evidences from the cases of Brazil and South Korea. Technol Forecast Soc Change 2002; 69:653-80.

6. United Nations Development Programme. Human Development Report 2001: making new technologies work for human development. New York/Ox ford: Oxford University Press; 2001.

7. Achilladelis B, Antonakis N. The dynamics of technological innovation: the case of the pharmaceutical industry. Res Policy 2001; 30:535-88.

8. Pavitt K. Sectoral patterns of technical change: towards a taxonomy and a theory. Res Policy 1984; 13:343-73

9. Cockburn I, Henderson R. Publicly funded science and the productivity of the pharmaceutical industry. In: Jaffe AB, Lerner J, Stern S, editors. Innovation policy and the economy. v. 1. Cambridge: MIT Press; 2001. p. 1-34.

10. Toole A. The impact of public basic research on industrial innovation: evidence from the pharmaceutical industry. New Brunswick: Department of Agricultural, Food and Resource Economics, Rutgers University; 2008.

11. Roffe P, Tansey G, Vivas-Eugui D. Negotiating health: intelectual property and access to medicines. London: Earthscan; 2006.

12. Klevorick A, Levin R, Nelson R, Winter S. On the sources and significance of inter-industry differences in technological opportunities. Res Policy 1995; 24:185-205.

13. Jalonen H, Lehtonen A. Uncertainty in the innovation process. In: European Conference on Innovation and Entrepreneurship. http://www.virtupro ject.fi/wp-content/uploads/2011/02/ECIE2011_ Jalonen_Lehtonen_Uncertainty_in_the_innova tion_process.pdf (accessed on 10/Aug/2014).

14. Tironi LF, Cruz BO. Inovação incremental ou radical: há motivos para diferenciar? Uma abordagem com dados da PINTEC. Brasília: Instituto de Pesquisa Econômica Aplicada; 2008. (Texto para Discussão, 1360).
15. Albuquerque E, Cassiolato JE. As especificidades do sistema de inovação no setor saúde: uma resenha da literatura como introdução a uma discussão do caso brasileiro. Belo Horizonte: Federação das Sociedades de Biologia Experimental; 2000. (Estudos FeSBE, 1).

16. Delgado I. Social welfare, health and pharmaceutical industry: preliminary notes for a comparative analysis between England, Brazil and Argentina. London: Department of International Development, London School of Economics and Political Science; 2012. (Working Paper Series, 130).

17. Shadlen K, Fonseca EM. Health policy as industrial policy: Brazil in comparative perspective. Polit Soc 2013, 41:561-87.

18. Thune T. Medical innovation: radical breakthroughs and evolutionary system. Oslo: Center for Technology, Innovation and Culture, University of Oslo; 2013

19. Mahoney RT, Morel CM. A global health innovation system (GHIS). Innovation Strategy Today 2006; 2:1-12.

20. Gadelha C. Desenvolvimento, complexo industrial da saúde e política industrial. Rev Saúde Pública 2006; 40:11-23.

21. Marmor T, Wendt C. Conceptual frameworks for comparing healthcare politics and policy. Health Policy 2012; 107:11-20.

22. Lobato LVC, Giovanella L. Sistemas de saúde: origens, componentes e dinâmica. In: Giovanella L, Escorel S, Lobato LVC, Noronha JC, Carvalho AI, organizadores. Políticas e sistema de saúde no Brasil. Rio de Janeiro: Editora Fiocruz; 2012. p. 89-120.

23. Moran M. Governing the health care state. A comparative study of the United Kingdom, the United States and Germany. Manchester: Manchester University Press; 1999.

24. Swaan A. In care of the state. Cambridge: Polity Press; 1988.

25. Hacker J. The historical logic of national health insurance: structure and sequence in the development of British, Canadian, and U.S. Medical Policy. Studies in American Political Development 1998; 12:57-130

26. Immergut E. As regras do jogo: a lógica da política de saúde na França, na Suíça e na Suécia. Rev Bras Ciênc Soc 1996; 30:138-65.

27. Younkin P. Making the market: how the American pharmaceutical industry transformed itself during the 1940s. Berkeley: Department of Sociology, University of California; 2009.

28. Rosenberg N, Nelson R. American universities and technical advance in industry. Res Policy 1994; 23:323-48.

29. Critical Path Institute. Advancing science through cross-disciplinary collaboration. http://c-path. org/about/ (accessed on 16/Oct/2014).

30. National Institutes of Health. Accelerating medicines partnership (AMP). http://nih.gov/science/ amp/index.htm (accessed on 16/Oct/2014).

31. National Institutes of Health. NIH public-private partnerships program. http://ppp.od.nih.gov/ (accessed on 16/Oct/2014). 
32. USA-CTSA Consortium. About the CTSA consortium. https://www.ctsacentral.org/about-us/ctsa (accessed on 16/Oct/2014).

33. Rice T, Rosenau P, Unruh L, Barnes AJ, Saltman RB, Ginneken E. United States of America: health system review. Health Syst Transit 2013; 15:1-431.

34. Public Health Emergency, U.S. Department of Health \& Human Services. Biomedical Advanced Research and Development (BARDA). http://www. phe.gov/about/barda/Pages/default.aspx (accessed on $16 /$ Oct/2014).

35. Defense Advanced Research Projects Agency. DARPA. http://www.darpa.mil/default.aspx (accessed on 16/Oct/2014).

36. Lundvall K, Okholm H, Marcusson M, Jespersen ST, Birkeland ME. Can public procurement spur innovations in health care. http://www.vinnova.se/ upload/EPiStorePDF/CanPublicProcurementSpu rInnovations.pdf (accessed on 14/Nov/2014).

37. Boyle S. United Kingdom (England): health system review. Health Syst Transit 2011; 13:1-483.

38. Corley TAB. The British pharmaceutical industry since 1851. In: Richmond L, Stevenson J, Turton A, editors. The pharmaceutical industry - a guide to historical records. Surrey: Ashgate Publishing Ltd.; 2003. p. 116-32.

39. Association of the British Pharmaceutical Industry. Pharmaceuticals and the UK economy. http:// www.abpi.org.uk/industry-info/knowledgehub/ uk-economy/Pages/default.aspx (accessed on 10/ Dec/2011).

40. National Innovation Centre. NIC-NHS. http:// www.nic.nhs.uk/ (accessed on 04/Jan/2012).

41. National Institute for Health Research. NIHR. http://www.nihr.ac.uk/ (accessed on 13/Dec/2014).

42. Research and Development, Directorate, Department of Health. Best research for best health - a new national health research strategy. London: Research and Development, Directorate, Department of Health; 2006.

43. Hicks D, Katz J. Hospitals: the hidden research system. Sci Public Policy 1996; 23:297-304.

44. Busse R, Blümel M. Germany: health system review. Health Syst Transit 2014; 16:1-296.

45. Blümel M. The Germany healthcare system. In: Thomson S, Osborn R, Squires D, Jun M, editors. International profiles of healthcare systems. New York/Washington DC: The Commonwealth Fund; 2013. p. 57-65.

46. Ognyanova D, Zentner A, Busse R. Pharmaceutical reform 2010 in Germany: striking a balance between innovation and affordability. Erohealth (Lond) 2011; 17:11-3.

47. Vandoros KS, Irwin R, Nicod E, Casson M. Tender systems for outpatient pharmaceuticals in the European Union: evidence from the Netherlands, Germany and Belgium. http://ec.europa.eu/enterprise/sectors/healthcare/files/docs/study_pric ing_2007/tendering_systems_en.pdf (accessed on 08/Nov/2014).

48. Dominguez LI. Understanding technology adoption in the German pharmaceutical industry. In: DRUID Academy Winter 2003 Ph.D. Conference Aalborg. http://www.druid.dk/conferences/ winter2003/Paper/Lacasa.pdf (accessed on 30/ Nov/2014).
49. Verband Forschender Arzneimittelhersteller. The pharmaceutical industry in Germany. http://www. pharmine.org/wp-content/uploads/2014/05/VFAPharma-Industry-Germany-2008.pdf (accessed on 04/Nov/2014).

50. Federal Ministry of Education and Research. The pharmaceuticals initiative for Germany. http:// www.bmbf.de/en/10540.php (accessed on Nov/ 2014).

51. Federal Ministry of Education and Research. Health research framework programme of the Federal Government. http://www.gesundheits forschung-bmbf.de/_media/Gesundheitsforschun gsprogramm_engl_barrierefrei.pdf (accessed on 20/ Nov/2014).

52. Federal Ministry of Education and Research. The leading-edge cluster competition. http://www. bmbf.de/en/20741.php (accessed on 20/Nov/ 2014).

53. Tatara K, Okamoto E. Japan: health system review. Health Syst Transit 2009; 11:1-162.

54. Matsuda R. The Japanese health care system, 2013. In: Thomson S, Osborn R, Squires D, Jun M, editors. International profiles of healthcare systems. New York/Washington DC: The Commonwealth Fund; 2013. p. 76-83.

55. Ragin M. Why the Japanese don't export more pharmaceuticals: health policy as industrial policy. Calif Manage Rev 1990; 32:124-50.

56. Umemura M. The interplay between entrepreneurial initiative and government policy: the shaping of the Japanese pharmaceutical Industry since 1945. Business and Economic History On-Line 2007; 5:1-9.

57. Ministry of Health, Labour and Welfare of Japan. New vision for the pharmaceutical industry Aiming at the industry with international competitive power taking the mission of innovation. http:/ / www.mhlw.go.jp/bunya/iryou/shinkou/ dl/01_0001.pdf (accessed on 04/Dec/2014).

58. Japan Pharmaceutical Manufacturers Association. Pharmaceutical administration and regulations in Japan. http://www.jpma.or.jp/english/parj/ pdf/2012.pdf (accessed on 05/Dec/2014).

59. Japan Pharmaceutical Manufacturers Association. Interim review of the biotechnology strategy guidelines: an advisory committee meeting is held. http://www.jpma.or.jp/english/events/ topics/update/update27_b.html (accessed on 05/ Dec/2014).

60. National Bio Resource Project. Core facility upgrading program. http://www.nbrp.jp/ (accessed on 05/Dec/2014).

61. Ministry of Economy, Trade and Industry of Japan. Industrial cluster policy. http://www.meti.go.jp/ policy/local_economy/tiikiinnovation/industrial_ cluster_en.html (accessed on 06/Dec/2014).

62. European Federation of Pharmaceutical Industries and Associations. Research \& development: facts \& figures. http://www.efpia.eu/documents/38/67/ Facts-amp-Figures (accessed on 10/Dec/2014).

63. Eggleston K. Health care for 1.3 billion: an overview of China's health system. Stanford: Asia-Pacific Research Center, Stanford University; 2012. (Asia Health Policy Program Working Paper, 28). 
64. Ding J, Xue Y, Liang H, Shao R, Chen Y. From imitation to innovation: a study of China's drug R\&D and relevant national policies. Journal of Technology Management \& Innovation 2011; 6:1-13.

65. Delgado I. Política industrial na China, Índia e Brasil: legados, dilemas de coordenação e perspectivas. Brasília: Instituto de Pesquisa Econômica Aplicada; 2015. (Texto para Discussão, 2059).

66. Nolan P, Zhang J. The challenge of globalization for large Chinese firms. Geneva: United Nations Conference on Trade and Development; 2002.

67. KPMG. The changing face the of healthcare in China. http://www.kpmg.com/CN/en/Issues AndInsights/ArticlesPublications/Documents / Healthcare-in-China-201010.pdf (accessed on 15/ May/2013).

68. Delgado I. Política industrial para os setores farmacêutico, automotivo e têxtil na China, Índia e Brasil. Brasília: Instituto de Pesquisa Econômica Aplicada; 2015. (Texto para Discussão, 2087).

69. Ling C, Naughton B. The emergence of Chinese techno-industrial policy: from megaprojects to strategic emerging industries, 2003-2011. http://inctpped.ie.ufrj.br/spiderweb/pdf/Chen Ling_and_Barry_Naughton.pdf (accessed on 08/ Aug/2013).

70. Liu X, Cheng P. Is China's indigenous innovation strategy compatible with globalization? Honolulu: East-West Center; 2011. (Policy Studies, 61).

71. McGregor J. China's drive for 'indigenous innovation' - a web of industrial policies. http://www. uschamber.com/reports/chinas-drive-indigenousinnovation-web-industrial-policies (accessed on 10/Aug/2013).

72. Spigarelli F, Wei H. The rising Chinese pharmaceutical industry: local champions vs global players. http://www.academia.edu/4286513/The_rising Chinese_pharmaceutical_industry_local_champi ons_vs_global_players (accessed on 10/Aug/2014).

73. Wennerholm P, Scheutz AM. India's healthcare system - overview and quality improvements. http: / / www.tillvaxtanalys.se/download/18.5f09 7bc113eacc3d6d5140/1369033657507/direct_re sponse_2013_04.pdf (accessed on 25/Sep/2014).

74. Planning Commission Government of India. Eleventh five-year plan (2007-2012): social sector. v. II. New Delhi: Oxford University Press; 2008.

75. Planning Commission Government of India. Twelfth five-year plan (2012-2017): social sectors. v. III. New Delhi: Oxford University Press; 2013.

76. Ministry of Health \& Family Welfare, Government of India. Financing and delivery of health care services in India. New Delhi: National Commission on Macroeconomics and Health; 2005. (NCMH Background Papers).

77. Organisation of Pharmaceutical Producers of India. 46th annual report: 2011-2012. http://www. indiaoppi.com/sites/default/files/PDF\%20files / Annual-Report-46th-AGM-2011-12_1.pdf (accessed on 12/Aug/2013).

78. Ravichandran N. The Indian healthcare system. Erlangen: Siemens Healthineers; 2009. (Essay Series: Healthcare Systems).
79. Ray A. Aprendizagem e inovação na indústria farmacêutica indiana: o papel da IFI e outras intervenções políticas. RECIIS (Online) 2008; 2:74-80.

80. Kotwal A, Ramaswami B, Wadhwa W. Economic liberalization and Indian economic growth: what's the evidence? http://web-dev-01.econ.duke.edu/ bread/system/files/bread_wpapers/294.pdf (accessed on 12/Aug/2010).

81. Department of Science \& Technology, Government of India. Drugs \& pharmaceutical research. http:// www.dst.gov.in/scientific-programme/td-drugs. htm (accessed on 13/Aug/2013).

82. Bahia L. O SUS e os desafios da universalização do direito à saúde no Brasil: tensões e padrões de convivência entre o público e o privado no sistema de saúde brasileiro. In: Lima NT, Gerschman S, Edler F, Suarez JM, organizadores. Saúde e democracia no Brasil. Rio de Janeiro: Editora Fiocruz; 2005. p. 407-49.

83. Menicucci T. Público e privado na política de assistência à saúde: atores, processos e trajetórias. Rio de Janeiro: Editora Fiocruz; 2007.

84. Delgado GC. Previdência social e mercado no Brasil. Ciênc Cult (São Paulo) 2006; 58:44-5.

85. Furtado J, Urias E. Estuio sectorial - setor farmacéutico de Brasil. Buenos Aires: Centro Redes; 2010.

86. Shadlen K. The political contradictions of incremental innovation: lessons from pharmaceutical patent examination in Brazil. In: Seminário Internacional INCT-PPED - Promovendo Respostas Estratégicas à Globalização. http://www.ideiad.com. br/seminariointernacional/arquivo8.pdf (accessed on 13/Aug/2009).

87. Vargas M. Documento setorial: área farmacêutica. http://www.bndes.gov.br/SiteBNDES/export/sites/ default/bndes_pt/Galerias/Arquivos/empresa/pes quisa/pib/pib_sintese_econ_conhec_vfinal.pdf (accessed on 05/Oct/2011)

88. Capanema L, Palmeira Filho P. Indústria farmacêutica brasileira: reflexões sobre sua estrutura e potencial de investimento. Brasília: Banco Nacional do Desenvolvimento Econômico e Social; 2007.

89. World Intellectual Property Organization. World intellectual property indicators - 2013. Geneva: World Intellectual Property Organization; 2013. (WIPO Economics \& Statistics Series).

90. Chaudhuri S. The industry response: the Indian pharmaceutical industry after TRIPS. In: Chaudhuri S, Park C, Gopakumar KM, editors. Poverty reduction and HIV/AIDS. Five years into the product patent regime: India's response. New York: United Nations Development Programme; 2010. p. 19-72.

91. Instituto Brasileiro de Geografia e Estatística. Pesquisa de inovação: PINTEC-2011. Brasília: Instituto Brasileiro de Geografia e Estatística; 2011.

92. Programa das Nações Unidas para o Desenvolvimento. Relatório de Desenvolvimento Humano 2014. Sustentar o progresso humano: reduzir as vulnerabilidades e reforçar a resiliência. New York: Programa das Nações Unidas para o Desenvolvimento; 2014 


\section{Resumo}

O artigo discute as relações entre os sistemas de saúde e a indústria farmacêutica, concentrando-se no apoio do Estado à inovação farmacêutica. Salienta as trajetórias dos Estados Unidos, Reino Unido e Alemanha países desenvolvidos, paradigmáticos dos modernos sistemas de saúde (liberais, universais e corporativos), além do Japão, um caso de emparelhamento bemsucedido. Também enfatiza as trajetórias de China, Índia e Brasil, países em desenvolvimento, extensos, que experimentaram diferentes estratégias de emparelhamento, dispondo de sistemas de saúde e indústrias farmacêuticas com trajetórias e perfis diversos. Finalmente, com foco nas formas estatais de apoio à pesquisa em saúde, considera os mecanismos de conexão entre os sistemas de saúde e a indústria farmacêutica, avaliando as possibilidades, no Brasil, de fortalecer uma interação virtuosa que favoreça a expansão $e$ consolidação do sistema de saúde brasileiro - universal, conquanto segmentado - e a afirmação da indús tria farmacêutica nacional inovadora.

Indústria Farmacêutica; Sistemas de Saúde; Políticas Públicas; Desenvolvimento Sustentável; Inovação

\section{Resumen}

El artículo discute las relaciones entre los sistemas de salud y la industria farmacéutica, concentrándose en el apoyo del Estado a la innovación farmacéutica. Resalta las trayectorias de los Estados Unidos, Reino Unido y Alemania, países desarrollados, paradigmáticos de los modernos sistemas de salud (liberales, universales y corporativos), además de Japón, un caso de emparejamiento exitoso. También enfatiza las trayectorias de China, India y Brasil, países en desarrollo, extensos, que experimentaron diferentes estrategias de emparejamiento en este ámbito, disponiendo de sistemas de salud e industrias farmacéuticas con trayectorias y perfiles diversos. Finalmente, centrándose en las formas estatales de apoyo a la investigación en salud, se consideran los mecanismos de conexión entre los sistemas de salud y la industria farmacéutica, evaluando las posibilidades, en Brasil, de fortalecer una interacción virtuosa que favorezca la expansión y consolidación del sistema de salud brasileño -universal, pese a estar segmentado-, y la consolidación de la industria farmacéutica nacional innovadora.

Industria Farmacéutica; Sistemas de Salud; Políticas Públicas; Desarrollo Sostenible; Innovación

Submitted on 24/Mar/2015

Final version resubmitted on 29/Sep/2015

Approved on 02/Oct/2015 